\title{
Effects of land-use changes on soil properties based on reambulated soil profiles
}

\author{
Dániel BALLA, ${ }^{*}$ Tamás MESTER, ${ }^{1}$ László MÁRTA, ${ }^{1}$ \\ Dávid MOLNÁR, ${ }^{1}$ Norbert BARKÓCZI,${ }^{2}$ Marianna ZICHAR, ${ }^{3}$ \\ Ágnes BOTOS, ${ }^{1}$ Tibor József NOVÁK ${ }^{1}$
}

\footnotetext{
${ }^{1}$ Department of Landscape Protection and Environmental Geography, University of Debrecen e-mail: balla.daniel@science.unideb.hu,mester.tamas@science.unideb.hu,mlaci2093@gmail.com, davidmolnar19@hotmail.hu, botos.agnes@science.unideb.hu,novak.tibor@science.unideb.hu

${ }^{2}$ Department of Physical Geography and Geoinformatics, University of Debrecen e-mail: barkoczi.norbert@ science.unideb.hu

${ }^{3}$ Department of Computer Graphics and Image Processing, University of Debrecen e-mail: zichar.marianna@inf.unideb.hu
}

Manuscript received September 14, 2017; revised September 30, 2017

\begin{abstract}
In our study, by investigating reambulated soil profiles from the NagySárrét region in Hungary, we attempt to determine the extent of changes which have occurred due to effects which impacted the landscape in terms of the soil chemistry properties of soil profiles exposed during the Kreybig soil survey more than 70 years ago. Based on the results, in the areas used as grassland, we observed a decrease in $\mathrm{pH}$ and an increase in the humus content of the topsoil. The increased $\mathrm{CaCO}_{3}$ following the chemical improvement of the soil which was used as cropland is still characteristic of the area. During the past decades, the investigated soils have been affected by significant changes with regard to water management, which have also modified the investigated parameters. We have classified the reambulated soil profiles among the Solonetz, Vertisol, and Gleysol reference groups based on the World Reference Base of Soil Resources (WRB) diagnostic system.
\end{abstract} WRB

Keywords: archive soil data, land use changes, Kreybig, Solonetz, Vertisol, Gleysol, 


\section{Introduction}

Soils are constantly changing due to natural and anthropogenic effects [1]. When the landscape changes, the modification of one or more landscape factors leads to the modification of other factors, thereby altering the entire landscape [2]. As a result of soil recording attempts which date back more than 100 years on the national level, a large amount of soil data is now available. One of the most notable of the attempts mentioned above has been the Kreybig soil survey, which was the first large-scale Hungarian soil recording carried out on a national level and covering the entire country $[2,3]$. During the last $70-75$ years, however, both the land use and the nature of the landscape have undergone significant changes. We aim to determine the extent of changes which have occurred due to the effects on the landscape in terms of the soil chemistry properties of soil profiles. We have done this by investigating the reambulated soil profiles in the study area of NagySárret, comparing them with the characteristic soil profiles of the Kreybigmapping. Based on the field recordings, we have also attempted to classify the reambulated soil profiles according to the World Reference Base for Soil Resources (WRB) diagnostic system.

\section{Materials and methods}

\section{Study area}

The study area is located in the eastern part of the Nagy-Sárrét microregion of the Great Hungarian Plain (Fig. 1). The numbering of the soil profiles is in accordance with the Kreybig soil database available for the area. Profile no. 8 is located north-west of Biharnagybajom, profile no. 46 is located north of Biharnagybajom, while profile no. 37 can be found south of Biharnagybajom. Nagy-Sárrét is a recent alluvial plain interspersed with alkaline lands and floodfree areas [5]. Part of it has basin-like characteristics, where in the deeper, artificially drained areas, croplands and small fragments of natural vegetation can be found [6]. Other areas of Nagy-Sárrét are covered with soils characteristic of abandoned river beds, natural levees, and highlands. Dispersed afforestation (mainly pedunculate oak and black locust trees) can also be found. The majority of meadows are used as pastures and croplands. All the soils of the landscape have been developed under the influence of shallow groundwater and partially of temporary surface water cover, which is reflected in the topsoil but more frequently in the subsoil properties [7]. As a result of anthropogenic activities, these soils are mostly artificially drained, which is expressed in the lowering of the groundwater level and the retreat of surface water cover [8]. 
The most important changes regarding the development of the landscape occurred as a result of the water management in the $19^{\text {th }}$ century [9], which prevented the yearly water coverage, resulting in an increase in aridification and a decrease in the ground-water level. With regard to the flora, two main types can be identified. First, the agriculturally cultivated annual plant cultures and, second, the natural flora, which can be found sporadically throughout the area. In river basin locations which used to support the Sárrét saline soils, grasslands and swamps can be found, while the dead basins mainly feature croplands and borderlands. In the spring, another characteristic feature is the presence of wet-meadow-foxtail grasslands, which dry by the summer [10].

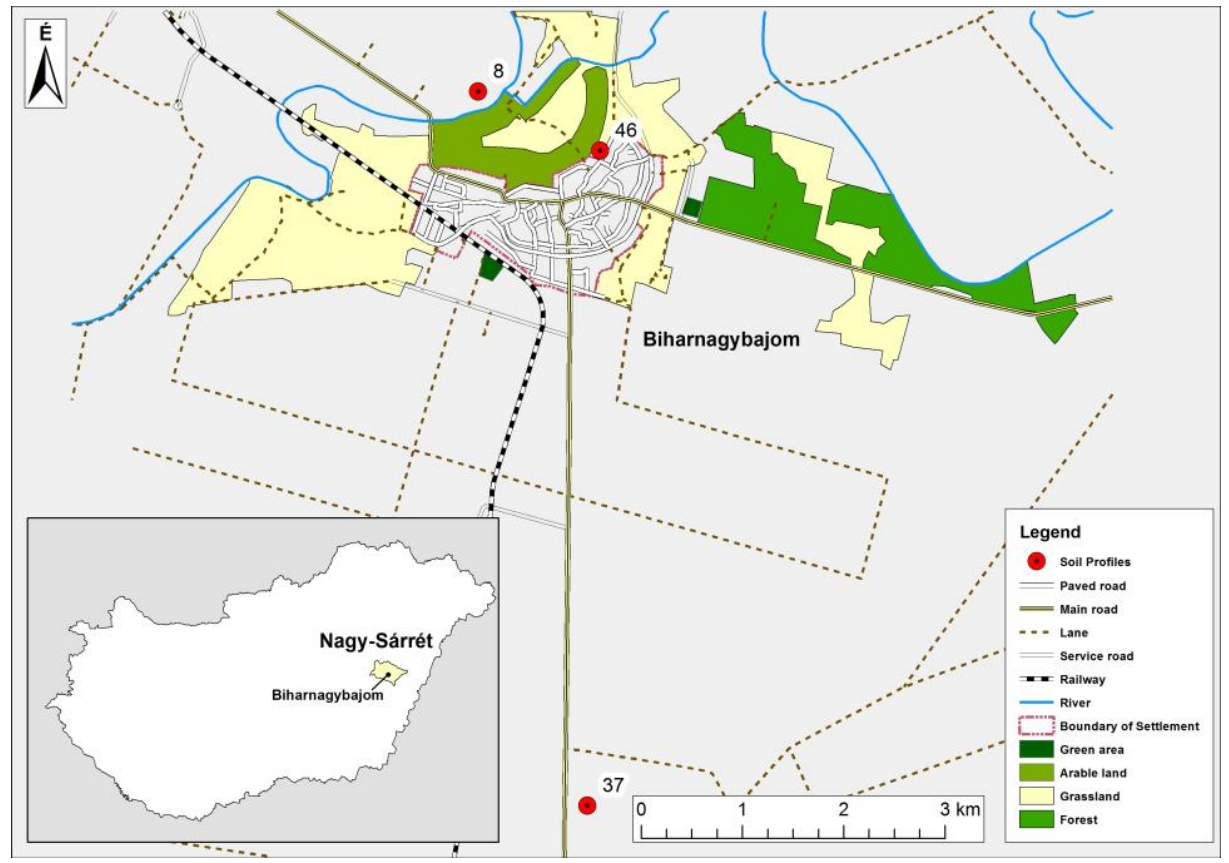

Figure 1. Location of study area.

Kreybig soil survey

In Hungary, Kreybig soil survey was the first national-level, large-scale local recording based on soil and laboratory investigations and was primarily intended to serve practical purposes $[11,12]$. The comprehensive, national recording of soil types led by Lajos Kreybig started in 1934 and aimed to create a series of thematic soil maps which can be used to determine the soil properties by revealing the physiological conditions in terms of the animals living in the soil as well as the 
plants grown for crops. The recording work was performed on the basis of 1:25,000-scale topographic maps in accordance with the profile boundaries. Exposing drillings were performed for the recordings, some of which were up to 10 meters deep or as deep as the level of the ground-water [13]. Up to 1944, 108 map profiles were published, and more than 250 map profile recordings were performed. The missing profiles and the ones destroyed during the war were not completely replaced until 1951. The chemical properties of the soil for particular locations are depicted using colours, while its physical properties are indicated with surface-filling patterns. On the printed map profiles, the nutrition quantity and the ground-water depth of the given point were indicated with identification numbers. One of the characteristics of the Kreybig-method is that the soil spots of the maps are associated with one representative and several further soil profiles which can be found within the given point [14].

\section{Soil description and classification according to WRB}

The primary reason for creating the World Reference Base of Soil Resources (WRB) is the international contribution to the development of the FAO. The first version of the WRB was introduced at the $15^{\text {th }}$ World Congress of Soil Science in Acapulco, Mexico in 1994. At the Congress, the researchers emphasized that by creating the WRB the goal was not the development of a new soil classification system but rather the harmonization of the different national systems $[15,16]$. The system is based on the diagnostic approach to soil classification, using well-defined terminology and quantitative parameters. Currently, the fourth version of the WRB - published in 2015 and currently valid [17] - is based on principal and supplementary qualifiers rendered to the RSG.

\section{Sampling and analysis}

For the selection of representative profiles, we used Kreybig 1:25,000-scaled maps with the identification number 5166/2, which were made available to us by the Institute for Soil Sciences and Agricultural Chemistry of the Hungarian Academy of Sciences (MTA ATK, TAKI) [18]. We collected both undisturbed and disturbed samples from the horizons of the three soil profiles selected for investigation. Following the establishment of the soil pit, we performed the environmental description of the soil profiles based on the FAO instructions [19] and collected samples from every distinguishable genetic horizon as well as from the layers described in the Kreybig information sheets for the purposes of laboratory investigations $[20,21]$. We determined the soil chemistry (based on Hungarian Standard 08-0206/2, 20135) and soil physics (based on Hungarian Standard 08-0205) properties from the collected disturbed samples. During the soil chemistry laboratory investigations, we measured the $\mathrm{pH}\left(\mathrm{H}_{2} \mathrm{O}\right)$, the carbonate and 
humus content (\%) as well as the conductivity ( $\left.\mathrm{EC}_{1: 2.5}\right)$. The texture class of the samples was determined using decantation (the Köhn-pipette method).

\section{Results and discussions}

Based on the Kreybig-database, we reambulated three exposed soil profiles in the study area (Fig. 2).
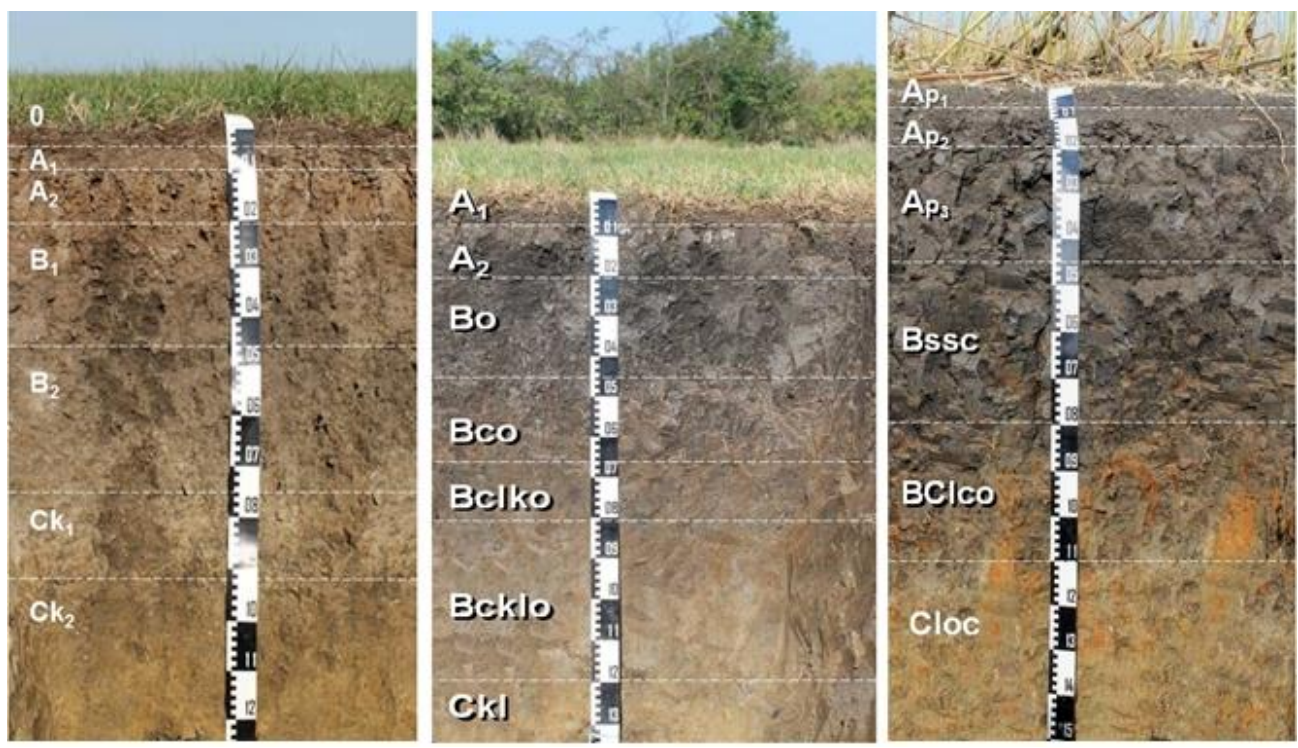

Figure 2. Soil profiles $(8,37,46)$

During the description of soil profile no. 8, we identified the following genetic horizons: $O$ horizon ranging from 0 to $3 \mathrm{~cm}$. Its humus content is high $(7.5 \%)$ and has an acidic $\mathrm{pH}\left(\mathrm{pH}\left(\mathrm{H}_{2} \mathrm{O}\right): 5.2\right)$. A horizon is located between 3 and $20 \mathrm{~cm}$. We divided this horizon into an $A_{1}$ subhorizon $(3-10 \mathrm{~cm}$ ) (eluvial, or leaching topsoil layer) and an $A_{2}$ subhorizon $(10-20 \mathrm{~cm}$ ) (humus layers, which accumulate during the process of incomplete mineralization). Its humus content is lower than that of the horizon above, but in terms of $\mathrm{pH}$ there is no significant difference between the two horizons. B horizon is also classified into two subhorizons. $B_{1}$ subhorizon (20$45 \mathrm{~cm}$ ) indicates an accumulation or transitional subhorizon, while $B_{2}$ subhorizon $(45-75 \mathrm{~cm})$ refers to a horizon where carbonates of pedogenic origin were accumulated. The reason for dividing $B$ horizon into two separate subhorizons is that we observed carbonate precipitations in $B_{2}$ subhorizon, but since the two subhorizons are identical in terms of their texture and structure the introduction of another genetic horizon seemed unnecessary. $C_{k}$ horizon can be found below a 
depth of $75 \mathrm{~cm}$ and ranges down to $92 \mathrm{~cm}$. In this horizon, we can observe small amounts of carbonate precipitations; however, these precipitations are amplified in $C_{k 2}$ horizon, where iron concretion can be seen as well.

Within the A horizon of soil profile no. 37, both $A_{l}$ and $A_{2}$ subhorizons can be identified. The depth of $A_{1}$ subhorizon is $0-7 \mathrm{~cm}$, and it is rich in humus and organic material. $A_{2}$ subhorizon is also rich is humus, but its structural elements show slight differences. Between $20 \mathrm{~cm}$ and $45 \mathrm{~cm}$, we can find a transitional subsoil horizon $(B)$; because here we can observe iron-oxide accumulations, we identified this horizon as $B_{o}$. Between $45 \mathrm{~cm}$ and $65 \mathrm{~cm}$, we can find $B_{C O}$ horizon, where the precipitation of iron-oxides is amplified and other carbonate precipitation can also be seen. Between $65 \mathrm{~cm}$ and $80 \mathrm{~cm}, B_{\text {clkol }}$ horizon can be found, where indications of gley processes can be observed in addition to the precipitations and the iron and carbonate concretions. The rate of conductivity is very high $(3.48 \mathrm{mS} / \mathrm{cm})$. The next one, $B_{\text {clkor }}$ horizon, can be found between $80 \mathrm{~cm}$ and $120 \mathrm{~cm}$, where carbonates of pedogenic origin, iron-oxide precipitations, and extensive gley processes can be observed. In terms of conductivity, differences can be observed from the previous horizon, although a relatively high value was measured here, as well $(2.24 \mathrm{mS} / \mathrm{cm})$. The high concentration of water-soluble salts can be explained by the raised ground-water level. $C_{k l}$ horizon can be found between $120 \mathrm{~cm}$ and $135 \mathrm{~cm}$, where the ratio of carbonates of pedogenic origin and the iron-oxide precipitations are high, and gley processes can be observed as well; however, the concentration of water-soluble salts is only $1668 \mu \mathrm{S}$.

The A horizon of profile no. 46 has been divided into three parts. $A_{p l}$ subhorizon (between 0 and $5 \mathrm{~cm}$ ) is a dark-coloured topsoil layer with humus accumulations and a great amount of organic material. It is a subhorizon disturbed by being used as cropland, as cultivated areas, or in other ways. This subhorizon is followed by $A_{p 2}$ subhorizon (between 5 and $20 \mathrm{~cm}$ ), which is also rich in organic materials and characterized by a dark-coloured topsoil layer and also affected by agricultural activity. $A_{p 3}$ subhorizon can be found between 20 and $45 \mathrm{~cm}$, and we can observe humus accumulation here, as well; however, it is only periodically disturbed by cultivation. The $\mathrm{pH}$ of all three subhorizons is slightly acidic or neutral. Between $45 \mathrm{~cm}$ and 80 , we can find a $B_{\text {ssc }}$ horizon, where "slickensides" can be observed. In addition, we also identified iron-oxide precipitations which formed due to decay. In terms of $\mathrm{pH}$, the topsoil was slightly acidic, while the subsoil was slightly alkaline. Next, we identified a transitional horizon ranging from $80 \mathrm{~cm}$ to $110 \mathrm{~cm}\left(B C_{l c o}\right)$, where $B$ and $C$ horizons overlap. The accumulation of 1.5 oxides and their hydroxides which formed due to decay is amplified, and carbonates of pedogenic origin also appear. Furthermore, signs indicating gley processes were observed. Between 110 and $160 \mathrm{~cm}$, we can find $C_{\text {loc }}$ horizon. This horizon is very loamy. The accumulation of iron-oxides and carbonates is more extensive compared to the above horizon. Its $\mathrm{pH}$ is neutral. 
The results of the profile descriptions and the profile environment records are included in Table 1 and Table 2.

Table 1. Environmental descriptions of investigated soil profiles

\begin{tabular}{|l|c|c|c|}
\hline \multicolumn{1}{|c|}{ Profile ID } & $\mathbf{8}$ & $\mathbf{3 7}$ & $\mathbf{4 6}$ \\
\hline Location & Biharnagybajom & Biharnagybajom & Biharnagybajom \\
\hline Elevation & $90 \mathrm{~m}$ & $86 \mathrm{~m}$ & $86 \mathrm{~m}$ \\
\hline Date of reambulation & 2015.09 .21 & 2015.09 .22 & 2015.09 .23 \\
\hline Type of soil climate & mesic & mesic & mesic \\
\hline Type of soil moisture regime & ustic & ustic & ustic \\
\hline Parent material & clay and silt & clay and silt & clay and silt \\
\hline Geomorphology & plain & plain & plain \\
\hline Land use and vegetation & Extensive grazing & Annual field cropping & Short grassland \\
\hline Cultivated plants & - & wheat & - \\
\hline Anthropogenic influences & organic fertilizer & organic fertilizer & organic fertilizer \\
\hline
\end{tabular}


Table 2. Main characteristics of investigated soil profiles

\begin{tabular}{|c|c|c|c|c|c|c|c|c|c|}
\hline 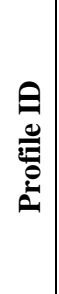 & 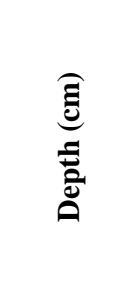 & 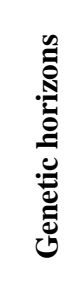 & 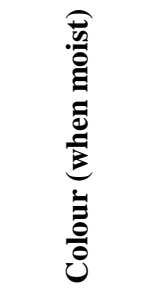 & 递 & 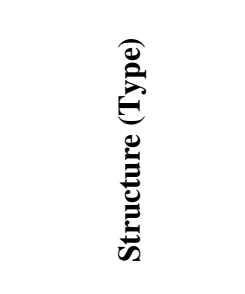 & 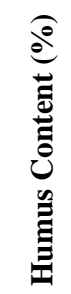 & 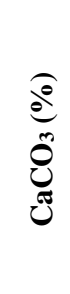 & 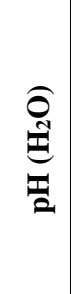 & 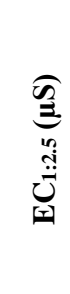 \\
\hline \multirow{7}{*}{8} & $0-2-3$ & 0 & - & - & - & 7.5 & 5.8 & 5.2 & 251 \\
\hline & $3-10$ & A1 & $10 \mathrm{YR} 2 / 2$ & loam & granular & 5.5 & 8.1 & 5.3 & 150 \\
\hline & $10-20$ & A2 & $10 \mathrm{YR} 2 / 2$ & silty clay loam & blocky/prismatic & 4.1 & 9.1 & 5.5 & 135 \\
\hline & $20-45$ & B1 & 10YR2/1 & silty clay loam & prismatic & 3.9 & 8.2 & 6.6 & 250 \\
\hline & $45-65$ & B2 & 10YR 3/1 & silty clay loam & $\begin{array}{c}\text { blocky/subangular } \\
\text { blocky }\end{array}$ & 1.8 & 11.8 & 7.8 & 323 \\
\hline & $65-105$ & $\mathrm{C}_{\mathrm{k} 1}$ & $10 \mathrm{YR} 3 / 2$ & silty clay loam & subangular blocky & 0.7 & 24.9 & 8.2 & 245 \\
\hline & $105-130$ & $\mathrm{C}_{\mathrm{k} 2}$ & $10 \mathrm{YR} 4 / 6$ & silty clay loam & subangular blocky & 0.7 & 24.6 & 8.4 & 231 \\
\hline \multirow{7}{*}{37} & $0-7$ & $\mathrm{~A}_{1}$ & 10YR 2/1 & silty loam & $\begin{array}{c}\text { subangular- } \\
\text { blocky }\end{array}$ & 4.9 & 9.4 & 7.5 & 588 \\
\hline & $7-20$ & $\mathrm{~A}_{2}$ & 10YR 2/1 & silty loam & blocky-prismatic & 4.1 & 7.8 & 7.7 & 628 \\
\hline & $20-45$ & $\mathrm{~B}_{\mathrm{o}}$ & $10 Y R 2 / 1$ & silty loam & blocky-prismatic & 2.8 & 8.9 & 7.9 & 1103 \\
\hline & $45-65$ & $\mathrm{~B}_{\mathrm{co}}$ & $10 \mathrm{YR} 2 / 2$ & loam & $\begin{array}{l}\text { subangular- } \\
\text { blocky }\end{array}$ & 1.4 & 8.2 & 7.8 & 2480 \\
\hline & $65-80$ & $\mathrm{~B}_{\text {clko }}$ & $10 Y R 2 / 2$ & silty clay loam & $\begin{array}{l}\text { subangular- } \\
\text { blocky }\end{array}$ & 0.7 & 9.5 & 7.7 & 3480 \\
\hline & $80-120$ & $\mathrm{~B}_{\text {clko }}$ & $2.5 \mathrm{Y} 3 / 2$ & clay loam & $\begin{array}{l}\text { subangular- } \\
\text { blocky }\end{array}$ & 0.8 & 20.6 & 7.9 & 2240 \\
\hline & $120-130$ & $\mathrm{C}_{\mathrm{kl}}$ & $2.5 \mathrm{Y} 4 / 2$ & clay loam & $\begin{array}{l}\text { subangular- } \\
\text { blocky }\end{array}$ & 0.7 & 25.8 & 8 & 1668 \\
\hline \multirow{6}{*}{46} & $0-5$ & $A_{p 1}$ & 10YR 2/1 & silty clay loam & $\begin{array}{c}\text { subangular- } \\
\text { blocky/granular }\end{array}$ & 7.18 & 7.1 & 6.8 & 497 \\
\hline & $5-20$ & $A_{p} 2$ & 10YR 2/1 & clay loam & $\begin{array}{c}\text { subangular/ } \\
\text { angular blocky }\end{array}$ & 7.36 & 6.1 & 6.8 & 395 \\
\hline & $20-45$ & $\mathrm{~A}_{\mathrm{p} 3}$ & $2.5 \mathrm{Y} 2 / 1$ & clay loam & massive & 7.38 & 6.3 & 6.7 & 279 \\
\hline & $45-80$ & $\mathrm{~B}_{\mathrm{ssc}}$ & 10YR $3 / 2$ & clay & angular-blocky & 2.19 & 6 & 6.7 & 251 \\
\hline & $80-110$ & $\mathrm{BC}_{\mathrm{lco}}$ & $2.5 \mathrm{Y} 4 / 3$ & clay & $\begin{array}{c}\text { subangular- } \\
\text { blocky }\end{array}$ & 1.67 & 13.3 & 7.9 & 391 \\
\hline & $110-160$ & $\mathrm{C}_{\text {loc }}$ & $5 Y 4 / 4$ & clay & $\begin{array}{l}\text { subangular- } \\
\text { blocky }\end{array}$ & 0.98 & 12.6 & 7.7 & 2250 \\
\hline
\end{tabular}




\section{Changes of soil properties}

Based on the laboratory results and the data which can be found in the Kreybig information book, changes in soil chemistry properties could be detected in certain cases (Fig. 3). In terms of $\mathrm{pH}$, significant acidification could not be detected, although the $\mathrm{pH}$ of the reambulated profiles decreased by at least 1 and in some cases 2 units. This is not regarded as a significant change considering the different measurement methods and the extent of the differences they produced.

In terms of $\mathrm{CaCO}_{3}$ content, comparison was not possible in the case of profile no. 37 due to missing data, although in the cases of profiles no. 8 and no. 46 it showed a significant increase (Fig. 3). The primary reason for this is that, in order to improve the soil quality, attempts were made to increase the capacity of the soil by calcification.

The humus content showed an almost twofold increase in the layers close to the surface (Fig. 3). The increased humus content can be explained by the altered land use. Currently, profiles no. 8 and no. 46 are used as pastures; therefore, the litter accumulating under the grass coverage contributes to a large extent to the increase in the organic material content of the soil.
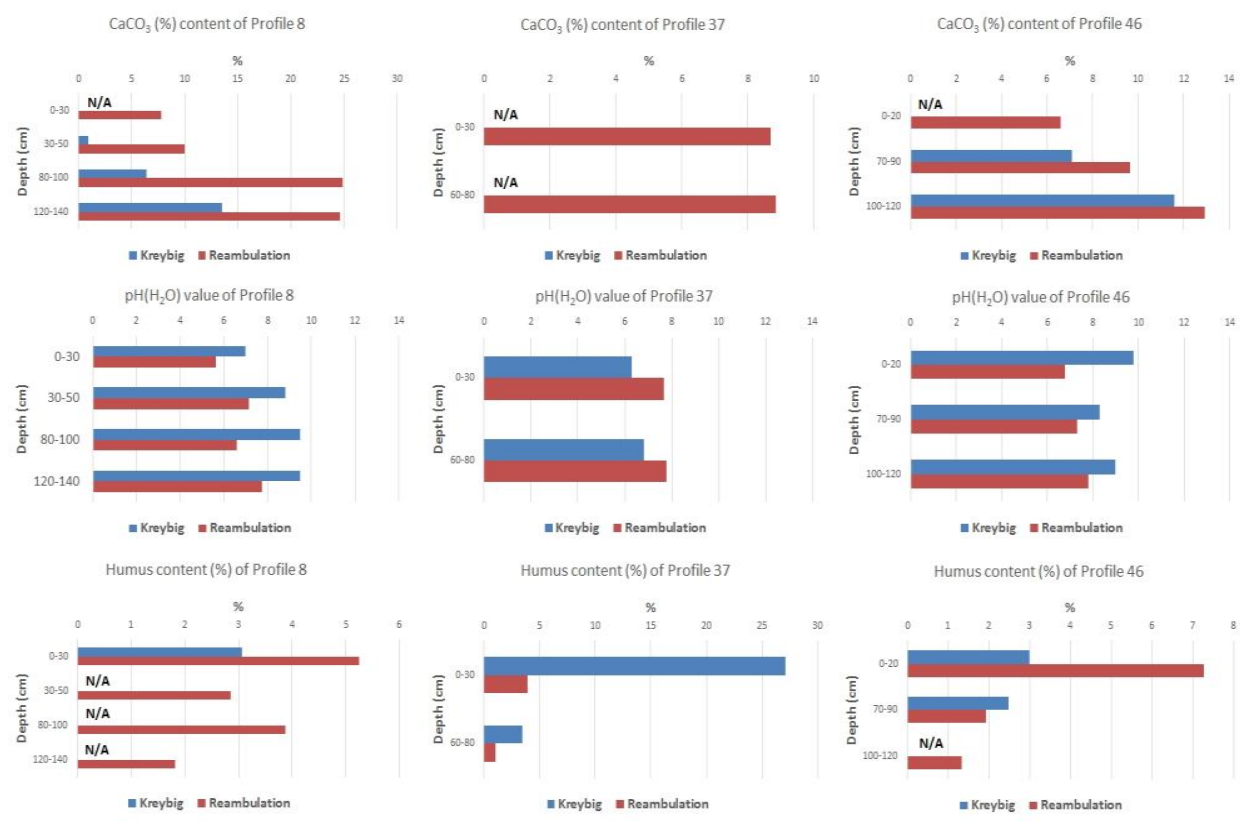

Figure 3. Changes of the chemical properties of the investigated soil profiles 


\section{Landscape changes as a result of land use}

In the Nagy-Sárrét areas where the soil profiles were located, landscape changes of varying extent have occurred during the past seven decades, which indirectly affected the development of soils. At the time of the profiling, soil profile no. 8 was described as a saline soil, which can be used as cropland only to a limited degree or under specific conditions. Therefore, attempts were made to improve the soil capacity by calcification in order to make it suitable for agricultural activity. At the same time, the previously cultivated areas are now used as pasture or hayfield. Profile no. 46 was described as a predominantly neutral or slightly alkaline soil, and calcification was used in order to improve soil capacity. The traces of these activities can also be observed today, although these areas have since been built up. As a consequence of the drainage works performed in the past, ground-water level decreased, and due to anthropogenic effects this area is also currently used as pasture. Profile no. 37 was previously described as a wetland soil. However, during our field investigations, neither the thick peat layer nor any other organic-material-accumulating zone could be identified. This can be explained by the fact that following drainage it has been oxidized as a result of the increased soil ventilation due to agricultural activity and periodic crop burnings. Soil development is largely affected by the fact that the crop yields of the currently cultivated annual plant cultures are regularly irrigated by the irrigation canals, which can be found close to the area.

\section{Results of WRB classification}

Table 3 includes the soil profiles classified on the basis of the WRB criteria sets for 2014. Profile no. 8 was classified among the Solonetz reference soil group based on the morphological features (the mobilization of clay and humus materials is indicated by the accumulation in $B$ horizon). Because of the high $\mathrm{CaCO} 3$ content $(24.9 \%)$ and because it has a deep humic, base-saturated mollic horizon, the calcic and mollic principal have been rendered to the profile. The iron and rust spots found in the lower layer indicate capillary increasing water and periodic anaerobic conditions, based on which the principal gleyic has been rendered to the profile. As a supplementary, the loamic qualifiers have also been added because of its texture class.

In the case of profile 46, the requirements of the Gleysol reference soil group have been met. As a prefix, the calcic qualifier has been used because of the high $\mathrm{CaCO} 3$ content $(25.56 \%)$. Furthermore, because it has a deep humic, basesaturated mollic horizon, the mollic principal has also been added. As a supplementary, the loamic qualifier has been added because of its texture class.

In the case of profile 37, the requirements of the Vertisol reference soil group have been met. The reason for this is the presence of the vertic horizon and the 
high clay content as well as the specific morphological features (slickenside, wedge-shaped structural elements, and shrink-swell cracks). As a prefix, we have used the grumic qualifier since a 7-cm-thick layer was observed on the surface, which was heavily structured, and the size of the structural elements was small. The iron and rust spots that can be found in the lower layer indicate capillary increasing water and periodic anaerobic conditions, based on which the prefix gleyic has been rendered to the profile. As a suffix, we have used the humic and pellic qualifiers. The humic qualifier has been added because of the fact that the profile had an organic carbon content higher than $1 \%$ on a weighted average down to a depth of $50 \mathrm{~cm}$ from the surface of the mineral soil layer in the fine earth fraction. The pellic qualifier has been used because down to a depth of $30 \mathrm{~cm}$ from the surface the wet Munsell colour score was lower than 3.5 and its colour saturation was lower than 1.5.

Table 3. Classified profiles according to WRB (2014)

\begin{tabular}{|c|c|c|c|}
\hline Profile ID & principal qualifiers & WRB RSG & supplementary qualifiers \\
\hline $\mathbf{8}$ & Calcic, Gleyic, Mollic & Solonetz & (Loamic) \\
\hline $\mathbf{3 7}$ & Grumic, Gleyic & Vertisol & (Humic, Pellic) \\
\hline $\mathbf{4 6}$ & Calcic, Mollic & Gleysol & (Loamic) \\
\hline
\end{tabular}

\section{Conclusion}

In our study, after investigating the reambulated soil profiles in the NagySárrét study area and comparing them to the data characterizing the profiles from the Kreybig mapping, we have come to the following conclusions. During the past seven decades, landscape and land-use changes of varying extent have occurred which indirectly impacted the state of soils and therefore their chemical and physical properties. In terms of $\mathrm{pH}$, no significant change could be identified. Due to the improvement in soil quality (calcification), the lime content has increased in the agricultural areas. In the areas currently used as pastures, the humus content of the topsoil has increased. In the croplands which used to be characterized by wetland soil, however, the organic material content of the topsoil has decreased.

\section{References}

[1] Kerényi, A. (2007), Tájvédelem. Debrecen: Pedellus Tankönyvkiadó.

[2] Kertész, Á. (2010), Hogyan értékelheti a tájváltozást? In: Szilassi P.-Henits L. (eds.), Tájváltozás értékelési módszerei a XXI. Században. Tudományos konferencia és mühelymunka tanulmányai. Szeged, 89-95. 
[3] Pásztor, L., Szabó, J., Bakacsi, Zs., Matus, J., Laborczi, A. (2012), Compilation of 1:50,000 scale digital soil maps for Hungary based on the digital Kreybig soil information system. Journal of Maps 8(3), 215-219.

[4] Pásztor, L., Szabó, J., Bakacsi, Zs. (2010), Application of digital Kreybig soil information system for the delineation of naturally handicapped areas in Hungary. Agrokémia és Talajtan 59(1), 47-56.

[5] Dövényi, Z. (2010), Magyarország kistájainak katasztere. MTA Földrajztudományi Budapest: Kutatóintézet.

[6] Martonné, E. K. (2008), Magyarország tájföldrajza. Debrecen: Kossuth Egyetemi Kiadó, 72-79.

[7] Balla, D., Novák, T., Zichar, M. (2017), Approximation of the WRB reference group with the reapplication of archive soil databases. Acta Universitatis Sapientiae, Agriculture and Environment 8(1), 27-38.

[8] Várallyay, Gy. (1997), A talaj funkciói. Magyar Tudomány 42(12), 1414-1430.

[9] Szilágyi, Zs. (2010), Berettyóújfalu és a Sárrét kapcsolatrendszere: A történeti földrajzi nézőpont egyik lehetséges olvasata. Bihari Diéta VI-VII. 101-126.

[10] Stefanovits, P. (1992), Talajtan. Budapest: Mezőgazda kiadó.

[11] Stefanovits, P. (1979), Kreybig Lajos 1879-1956. Agrokémia és Talajtan XXVIII(3-4), 353356.

[12] Pásztor, L., Szabó, J., Bakacsi, Zs. (2010), Digital processing and upgrading of legacy data collected during the 1:25.000 scale Kreybig soil survey. Acta Geodaetica et Geophysica Hungarica 45, 127-136.

[13] Kreybig, L. (1938), A M. Kir. Földtani Intézet talajfelvételi, vizsgálati és térképezési módszere és célja. Budapest, Magyar Mérnök- és Építész- Egylet.

[14] Pásztor, L., Szabó, J., Bakacsi, Zs., Laborczi, A. (2013), Elaboration and applications of spatial soil information systems and digital soil mapping at Research Institute for Soil Science and Agricultural Chemistry of the Hungarian Academy of Sciences. Geocarto International 28(1), $13-27$.

[15] Michéli, E., Fuchs, M., Hegymegi, P., Stefanovits, P. (2006), Classification of the major soils of Hungary and their correlation with the World Reference Base for Soil Resources (WRB). Agrokémia és Talajtan 55(1), 19-28.

[16] Michéli, E. (2011), A talajképző folyamatok megjelenése a diagnosztikai szemléletü talajosztályozásban, Agrokémia és Talajtan 60(1), 17-32.

[17] IUSS WORKING GROUP WRB. (2014), World Reference Base for Soil Resources 2014. International Soil Classification System for Naming Soils and Creating Legends for Soil Maps ( $3^{\text {rd }}$ ed.). Rome, FAO, 1-86.

[18] Han, F., Schimidt, E. R. (1941), Magyarázatok Magyarország geológiai és talajismereti térképeihez. Biharnagybajom, M.KIR. Földtani Intézet Budapest.

[19] FAO (Food and Agriculture Organization of the United Nations). (2006), Guidelines for soil description, Roma, Fourth edition, Rome, FAO.

[20] Buzás, I. (1988), Talaj- és Agrokémiai vizsgálati módszerkönyv 2: A talajok fizikai -kémiai vizsgálati módszerei. Budapest: Mezőgazdasági Kiadó.

[21] Keveiné, B. I., Farsang, A. (2002), Terep- és laborvizsgálati módszerek a természeti földrajzban. Szeged: JATEPress. 